\title{
A MULTIFACETED MODEL FOR DESIGNING READING DEVELOPMENT PROGRAMMES FOR L2 LEARNERS AT TERTIARY LEVEL
}

Naomi Boakye

University of Pretoria

Socio-affective issues are generally acknowledged as important in reading development. However, most intervention programmes focus on cognitive aspects of reading, and do not explicitly accommodate socio-affective factors such as attitude, motivation, interest, and background of students. This paper argues for the inclusion of both cognitive and socioaffective scaffolding in tertiary-level reading development programmes. Based on a number of second language teaching techniques, and grounded in Guthrie and Wigfield's (2000) engagement model, I propose a multifaceted model on which to map reading instruction/intervention at tertiary level that combines both affective and cognitive factors.

Keywords: socio-affective factors, engagement, reading development, teaching principles, multifaceted model

\section{INTRODUCTION}

Given the low literacy levels of students who enrol for tertiary studies, and the fact that their success at tertiary level depends on their ability to read and write academically, various attempts have been made at improving students' academic literacy. Most of these literacy development programmes have centred on reading and writing, and are purely cognitively oriented. In this paper, I argue for a reading intervention programme that comprises both the cognitive and the affective, such as motivation, attitude, interest, and self-efficacy.

In the sections that follow, I first discuss the acknowledgement of socio-affective factors in reading development, followed by a discussion on the paucity of research in this area, as well as the glaring exclusion of these factors from reading programmes. The next section provides an overview of the importance of socio-affective factors, including both theoretical and empirical support. Guthrie and Wigfield's (2000) Engagement model is presented and discussed within a reading instructional framework. Finally, a multifaceted model is presented, which takes cognisance of cognitive and socio-affective factors in second language (L2) reading instruction. 


\section{SOCIO-AFFECTIVE FACTORS IN READING DEVELOPMENT}

Contrary to traditional cognitive views, current views on reading development recognise the relevance of socio-affective factors. Anderson (1999) includes building motivation in his strategies for teaching second language reading. Greaney (1996) argues for reading instruction to focus more on instilling joy and pleasure in learners than on teaching cognitive skills. Verhoeven and Snow (2001:2) argue that, without some level of motivation, neither orthographic knowledge nor comprehension strategies are likely to develop optimally. They further argue that the notion of engagement in literacy requires redefining literacy itself to acknowledge the degree to which it is a social activity and an affective commitment, in addition to being a cognitive accomplishment (Ibid).

Serpell (2001), Street (2001) and Niven (2005) all acknowledge the influence of social factors in reading development, and argue for socio-cultural underpinnings to literacy development. Bus (2001) highlights the social aspect of reading development strongly in his study. He shows from his study that the interactive experience that children receive from their parents affects the frequency and quality of parent-child book reading and, consequently, the development of literacy. Grabe and Stoller (2002:37) concede that:

This emphasis on individual processes is not intended to deny the relevance of social factors on reading development (e.g. family literacy experience, primary schooling, and peer and sibling interaction around literacy events) or the relevance of social contexts on purpose and processes themselves...

Guthrie and Wigfield (2000:404) sum up these arguments when they state that, 'readers are decision makers whose affects as well as their language and cognition play a role in their reading practices'.

Despite social and affective factors having been acknowledged as important in reading development, there is, however, little research in this area.

\subsection{LIMITED RESEARCH ON SOCIO-AFFECTIVE READING PROGRAMMES}

There is no doubt that social and affective issues are considered as relevant in students' reading development. However, this has not been transferred to practical teaching. Verhoeven and Snow (2001:11) state that procedures for incorporating this acknowledgement into actual teaching practice are not widely implemented. Greaney (1996) and Elley (1996) lament that many teachers, especially in developing countries, still focus solely on skills in reading instruction. A number of reading intervention programmes, both nationally and internationally, are cognitively oriented, focussing mainly on skills such as word recognition, strategy use, reading speed and vocabulary development. Although cognitive programmes are well meaning and do achieve results, the outcomes could have been greater had the approach included socio-affective issues.

Besides being largely excluded in reading instruction, socio-affective factors have not been researched extensively in reading development (Day \& Bamford, 1998; Alderson, 2000; Pretorius, 2000; Grabe \& Stoller, 2002; Brunfaut, 2008). Grabe and Stoller (2002:57), in discussing the influence of socio-affective factors in reading development, state: 
No one disputes the fact that students' self-perceptions, emotional attitudes towards reading, interest in specific topics, willingness to read texts and learn from them are important issues for the classroom learning environment. Unfortunately these issues are often ignored in discussions of reading comprehension instruction... [Italics mine]

Commenting on the paucity of research in this area, they confirm that, although motivation is now generally viewed as important for learning, we lack a keen understanding of the relationships between motivation, attitudes, interest and attributions and their effects on L2 reading abilities (Grabe \& Stoller, 2002:76).

\subsection{IMPORTANCE OF SOCIO-AFFECTIVE FACTORS}

The importance of socio-affective factors cannot be overemphasised. Guthrie, Wigfield and Von Secker (2000), expounding on Stanovich's (1986) well-known concept of the Matthew effect (the rich get richer in reading proficiency), indicate that motivation mediates reading ability and, in L1 contexts, motivational factors are now seen as important predictors of academic success. Social factors, specifically the home environment, have been proven to be the most critical factor in learners' reading achievement (Greaney, 1996). Guthrie and Wigfield (2000) found that engaged reading, which is defined as 'a state of total absorption', or 'reading that is strategic and conceptual, as well as motivated and intentional', is strongly associated with reading achievement. In fact, they state that engagement in reading (which involves motivation and other affective indicators) is equivalent to several years of schooling, and may substantially compensate for low family income and poor educational background (Guthrie \& Wigfield, 2000:404).

Greaney (1996) and Elley (1996), in their separate discussions of the International Education Achievement (IEA) studies, concluded that reading for pleasure reaps more benefits than instruction that focuses on skills. Elley (1996:53) categorically states that:

Instructional programmes that stress teacher directed drills and skills are less beneficial in raising literacy levels than programs that try to capture students' interest and encourage them to read independently.

The importance of socio-affective factors is even more pronounced in L2 reading contexts. A number of students come from poor home and school reading environments, where the love of reading is not inculcated. These students, who have very low affective levels for reading and for whom academic reading poses huge challenges, have to compete with students who have been raised and educated within rich literacy environments and for whom reading is a regular and pleasurable occurrence. Grabe and Stoller (2002) indicate that L2 readers come to L2 classrooms with varying attitudes and motivational levels which affect their willingness to engage in reading activities. The influence of social and affective factors in L2 reading development and academic achievement is confirmed by Grabe and Stoller (2002), Greaney (1996), Pretorius (2000, 2002, 2007) and Niven (2005),

Given the strong views that Guthrie holds on the importance of affect in reading development, he and several of his colleagues have conducted a number of intervention programmes focusing on affective factors to develop students' reading proficiency. Of note is his Engagement Model that proposes a framework for teaching reading using an affective approach (Guthrie \& Wigfield, 2000:410). 
In addition to the theoretical support of social and affective factors in reading development, an empirical study undertaken with first-year University of Pretoria students confirms the influence of socio-affective factors in reading development. Students' responses to survey questionnaires on socio-affective factors and strategy use showed that their reading experiences, such as reading interaction with their family members, library visits as children, and promotion of reading at home and at school, aligned with their literacy levels (Boakye, forthcoming). In other words, students who had low academic literacy levels also had poor reading experience, low self-efficacy and low intrinsic motivation. Likewise, those on the highest academic literacy levels had a rich literacy experience, high self-efficacy and high intrinsic motivation.

\section{INSTRUCTIONAL FRAMEWORK AND ENGAGEMENT MODEL}

Both the theoretical discussion on the relevance and importance of socio-affective factors in reading development and the confirmation of a relationship between students' social and affective reading experiences on one hand, and the literacy levels or reading proficiency on the other, point towards a necessity for a socio-affective approach in reading instruction. In relation to this, Guthrie and Wigfield's (2000) model, which focuses on engagement through motivation to develop reading ability, is of relevance and is presented and explained below. The model and the instructional framework for teaching reading has been used in the United States with very high success, as reported in studies by Guthrie and his colleagues. The model is presented below and is followed by discussions of the instructional framework.

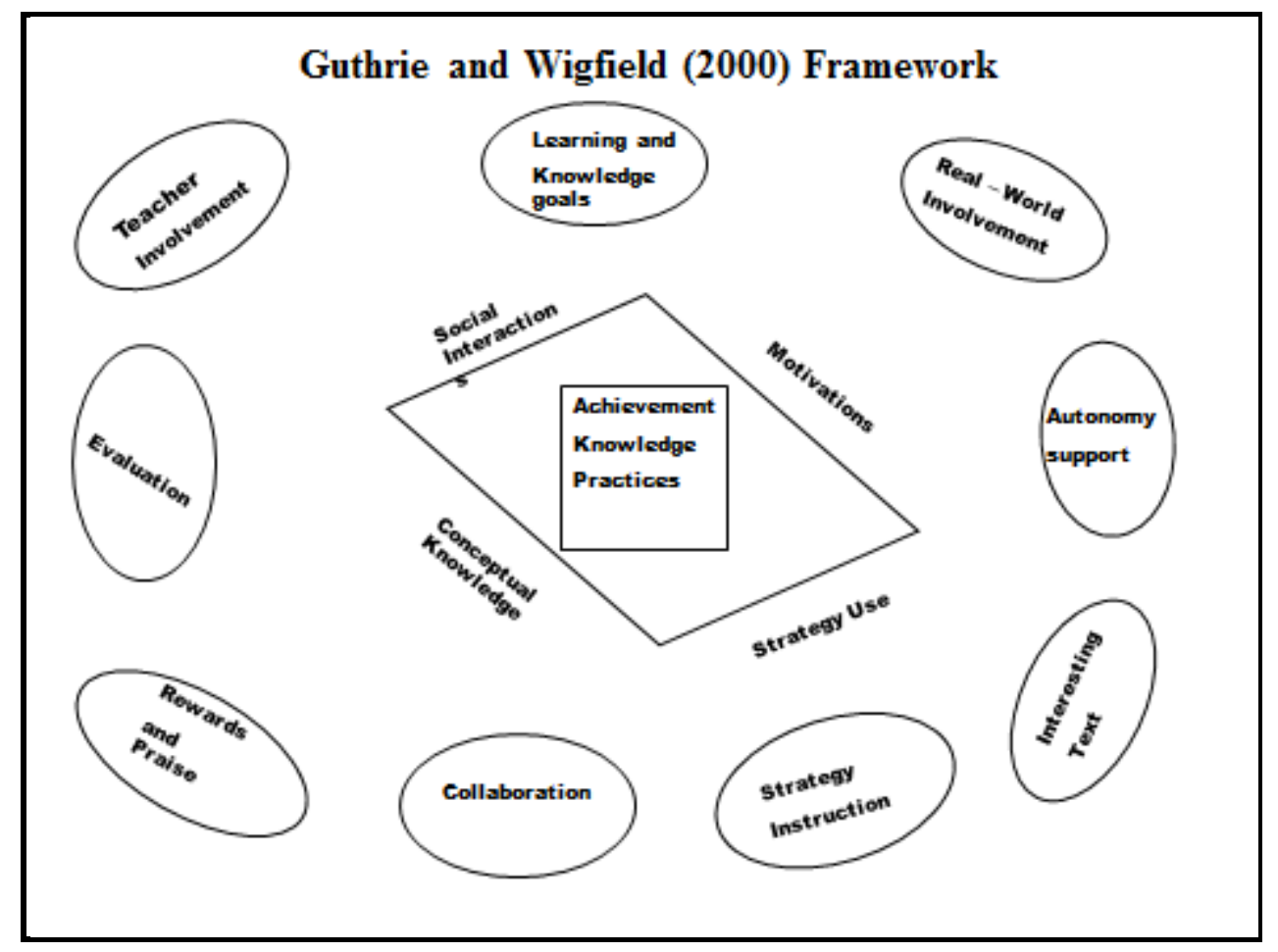

Figure 1: Guthrie and Wigfield's (2000) Engagement model for reading development

The above classroom techniques, introduced by Guthrie and Wigfield (2000) for motivating students, are based on the Self-determination Theory of Motivational Development by Deci et al. (1991). This theory describes the development of intrinsic motivation in terms of 
support for the individual's need for autonomy (making own choices), relatedness (collaborating with others), and competence (understanding of the attainment of outcomes) (Deci et al., 1991:326). Autonomy is provided through self-directed learning and choices; relatedness is addressed in collaborative classroom activities such as group discussions and projects. Self-perceived competence is achieved through strategy instruction, continuous assessment that is supportive, and rewards that acknowledge efforts put into learning. In essence, when students' needs for autonomy, relatedness and self-perceived competence are met, intrinsic motivation is created, which leads to gains in cognitive achievement in reading.

\subsection{CLASSROOM PRINCIPLES}

In relation to this view, Guthrie and Wigfield (2000) identify nine classroom principles (shown in the outer section of model) to be applied in creating the appropriate environment for fostering motivation and creating engaged readers.

- Learning goals

- Real-world involvement

- Autonomy support

- Interesting texts

- Strategy instruction

- Collaboration

- Praise and rewards

- Evaluation

- Teacher involvement

\section{Learning and knowledge goals}

This instructional technique refers to the purpose for learning and is linked to performance and learning goal theory. Whereas performance goals are based on outperforming others, learning goals are based on dedication to understanding and learning. Focus on learning goals produces long-term engagement and learning (Ames, 1992). Research showed that teachers who emphasised learning goals instead of performance goals contributed to students' selfefficacy. The assumption is that students put in more effort and applied strategies more effectively when they were made to believe that understanding the work was more important than getting right answers (Guthrie \&Wigfield, 2000:410).

\section{Real-world interactions}

These can be referred to as authentic interactions. They refer to connections between academic curricula and the personal experiences of students. Reading instruction embedded within intrinsically motivating activities that relate to students' personal experiences, such as collecting information, observing and reporting, led to increases in reading motivation and strategy use (Csikszentmihalyi, 1991; Brophy, 1998; Guthrie et al., 1998; Anderson, 1999; Guthrie et al., 1999). 


\section{Autonomy support}

Students' independence and responsibility is the focus of this technique. Its application to reading involves the teacher's guidance in leading students to make responsible choices in reading. Based on the convention that choice is motivating, the technique develops independence and affords students control over topics, themes and reading materials, with teacher support. Guthrie and Wigfield (2000:411) assert that individuals (students) prefer to be in command of their environment rather than to be manipulated by powerful individuals (teachers). With regard to motivation, Grolnick and Ryan (1987), Deci et al. (1991) and Sweet, Guthrie and Ng (1998), have shown benefits of autonomy support on intrinsic motivation and reading comprehension.

\section{Interesting texts}

The use of interesting texts (texts that are significant and readily understandable) is based on the assumption that texts that are personally significant and that meet the cognitive competence of students would be motivating, and consequently develop comprehension abilities. Grabe and Stoller (2002:30) argue that difficult texts that are beyond students' level of comprehension cause them to adopt coping strategies, which eventually lower their motivation for reading. Scaffolding using different levels of texts would enable students to approach difficult texts gradually without losing motivation. In addition, interesting texts assist in focusing reading instruction on word recognition and word fluency (Stanovich \& Cunningham, 1993; Elley, 1996; Morrow, 1996).

\section{Strategy instruction (competence support)}

This technique involves direct instruction of reading and comprehension strategies such as summarising, paraphrasing and synthesising through teacher modelling. A number of investigations have shown that strategy instruction increases intrinsic motivation and selfefficacy (Anderson, 1991; Schunk \& Zimmerman, 1997; Dreyer \& Nel, 2003; Worden, 2003).

\section{Collaboration (relatedness support)}

Social collaboration in the classroom was found to promote intrinsic motivation for reading and learning, and to maintain active learning over an extended period of time (Nolen \& Nichols, 1994; Wentzel, 1997). The argument that engaged readers share ideas and discuss literature with others is the basis for this teaching technique for reading development.

\section{Praise and rewards}

At tertiary level, praise and rewards could be in the form of marks, encouraging comments, and book awards. Although this concept is known to be beneficial, in that it increases selfefficacy and motivation, it could also have detrimental effects. Students can become extrinsically motivated and depend on performance goals, which involve the use of temporal and surface strategies such as memorisation and guessing. Their focus may be shifted to high grades, correct answers and completion of tasks, instead of comprehension and enjoyment. For praise and rewards to be beneficial, they should be given within what Wlodkowski 
(1985:182) calls 3S-3P. That is, 'praise should be sincere, specific and sufficient and should be properly given for praiseworthy success in the manner preferred by the learner'.

\section{Evaluation}

Evaluation in the form of tests, assignments and projects should reflect students' ownership and provide motivation for reading. Evaluations that are purely teacher centred are controlling and may cause anxiety and diminish intrinsic motivation, which may curtail conceptual learning. Personalised evaluations, such as projects and portfolios, may be difficult to administer but these contribute towards instilling motivations for reading. As a result, an integration of standardised and personalised evaluations in order to produce optimal results is suggested. Evaluating effort and progress (performance feedback) rather than absolute skills encourages success and enjoyment, and increases self-efficacy (Deci, Vellerand, Pelletier \& Ryan, 1991; Au \& Asam, 1996; Schunk \& Zimmerman, 1997).

\section{Teacher involvement}

The teacher's knowledge of individual students; care about their progress; and pedagogical understanding of how to foster their active participation (Guthrie \& Wigfield, 2000:416) are important avenues for increasing students' motivation and fostering engagement. Bus (2001) showed that children who interacted positively with their parents and received parents' attention had positive attitudes towards learning, and subsequently achieved success in learning. Skinner, Wellborn and Connell (1990) showed through empirical evidence that adult involvement promoted reading engagement in learners, which led to achievement in reading and other subjects. When students feel that significant adults such as parents and teachers are involved in their learning, they become motivated and strive towards success in learning.

\subsection{INNER CONSTRUCTS OF MODEL}

In addition to the instructional principles/framework discussed above, Guthrie and Wigfield's (2000) reading Engagement model includes constructs such as motivation, conceptual knowledge, strategy use and social interaction, which are shown in the centre of the diagram (Fig 1). This implies that, underlying all the instructional principles is motivation, which includes goals, intrinsic and extrinsic motivation, self-efficacy and social motivation. The assumption is that the motivational aspects of the reader propel him/her to choose to read and to do so using cognitive strategies to comprehend. The strategy aspect in the construct refers to the cognitive and metacognitive processes of comprehending, self-monitoring and constructing understanding. The conceptual knowledge facet refers to reading as knowledge driven and knowledge applied (in other words, content knowledge and background knowledge). Students are driven to seek knowledge and apply background knowledge to gain understanding. The social interaction facet of the diamond in the diagram points to reading as a social endeavour that refers to collaborative practices among students, inside and outside the classroom.

Achievement, knowledge, and reading practices are at the centre of the model, to show that achievement is the result of instructional practices with social and affective emphasis. Achievement is in the form of comprehension test results, and other literacy practices; knowledge is shown through standardised evaluations, and ownership of learning, for 
example portfolios; and reading practices are reflected in the amount and frequency of independent reading.

Guthrie and Wigfield (2000) believe that, if the principles are applied with a goal towards motivation, engaged reading will occur and students will reap the benefits related to engaged reading, such as conceptual use of strategies and conceptual learning, and thereby obtain success in reading and academic performance.

Guthrie and Wigfield's (2000) model is innovative, integrative and outcome-oriented. It aims to provide success in reading instruction. The model stands in contrast to a number of reading research and intervention programmes that have focused on cognitive processes alone. Guthrie and Wigfield (2000) argue that desired outcomes of teaching, such as text comprehension ability, knowledge acquisition from text, and sustainable reading practices, do not result automatically in response to reading instruction, but are mediated by engagement. Guthrie and his colleagues have reported great gains in intervention programmes on reading development based on their Engagement model and instructional framework, which consists of the classroom principles discussed above.

\section{L2 ISSUES AND TERTIARY TEACHING CONTEXT}

Given the reported success of Guthrie and Wigfield's (2000) model, it is recommended for use in reading programmes. However, in applying such a model to a multicultural and multilingual tertiary context in Africa, and in South Africa specifically, several issues need to be considered. First of all, most of Guthrie's subjects were primary and high school students whose reading demands are different from the demands at tertiary level. Academic reading at tertiary level demands a higher cognitive level of reading. As Boughey (2009) rightfully explains:

Universities require students to make inferences and draw conclusions from what they read, and to use reading of other texts and their knowledge of the world to question what they are reading.

Secondly, Guthrie and Wigfield's (2000) model does not relate to the distinction between L1 and L2 reading. L2 reading is now perceived as a phenomenon unto itself - reading that has its own complex issues and not just a kind of L1 reading in another language (Bernhardt, 1991:2). Bernhardt (1991:5) adds that there are various groups of second language readers (she identifies three groups of adults and two groups of children) who are very different from one another, and recognising the differences between and among these groups provides an initial step towards developing non-generic, more principled reading instruction. Thirdly, Guthrie and Wigfield's model does not explicitly draw attention to a needs analysis, although this aspect is crucial in an intervention programme. A needs analysis is necessary in order to tailor intervention to meet students' specific needs. It enables the teacher to become aware of students' needs and, consequently, to select teaching materials and activities that are significant, of interest to students and at their level of competence. Fourthly, whereas Guthrie and Wigfield (2000) focus on reading comprehension, academic reading goes beyond comprehension to encompass critical reading (such as integration, evaluation and synthesising) and academic vocabulary. 
The dynamics of academic reading at tertiary level, L2 reading issues, and a needs analysis are some of the factors that will be included in a modified version of Guthrie and Wigfield's model. These issues are discussed in relation to Bernhardt's (1991) principles, Butler's (2007) key elements and Kumaravadivelu's (2003) macrostrategies.

\subsection{PRINCIPLES PERTAINING TO L2 READING INSTRUCTION}

Bernhardt's (1991) first principle can be related to autonomy and choice in Guthrie and Wigfield's (2000) model. Bernhardt (1991) characterises this principle as allowing students to develop some understanding of a text. Her belief is that adult readers come into L2 reading with well-developed beliefs and understanding of the world and these greatly influence their reading in a second language. She suggests that teachers should assist learners to apply their background knowledge in understanding texts.

A second principle refers to flexibility in reading, in which instruction is perceived as working from students' understanding of L2 texts. This means that the teacher has to be strategic by analysing students' behaviour during instruction and modifying instruction to attend to those behaviours. In other words, the teacher should not pretend to anticipate which sections of a text or which aspects of reading comprehension students will find problematic, but should work from students' interpretation of the text.

The third principle refers to the fact that reader misunderstandings could arise from a variety of sources, both text-based (for example, grammatical and vocabulary) and knowledge-based (for example, cultural and social) and, therefore, an analysis of students' misunderstanding should encompass a broad spectrum of possible problem sources.

Her fourth principle states that reading instruction should be on individual readers (or specific groups) and their understandings. In other words, problems pertaining to individuals or specific groups should be dealt with rather than assumed to be generic difficulties. Difficulties that a teacher addresses within reading instruction should be ascertained from a specific group. In essence, a needs analysis is recommended for dealing with L2 reading challenges.

The last and fifth principle, according to Bernhardt (1991), is based on the previous four principles and states that second language reading instruction should be direct. Direct implies that a teacher should target instruction at problematic areas once a needs analysis has been done. The seemingly contrasting ideas in the first principle (autonomy and choice), and the fifth principle (teacher's direct instruction) is explained thus:

The principles imply a teacher who is simultaneously in and out of direct control of her classroom. On the one hand, instruction needs to be student-centred to provide the teacher with appropriate diagnostic material without the initial intervention of the teacher's 'best judgement'. On the other hand, instruction needs to be teachercontrolled so that students are not forced into 'faking it'. Rather, students need to be given resources they need as individuals to cope with second language texts (Bernhardt, 1991:187).

The contradiction is also evident in Guthrie and Wigfield's (2000) advocacy of learner autonomy and teacher involvement or support. According to these authors, although the two 
seem contradictory, one without the other will not produce optimum benefits. In relation to the five principles discussed above, Bernhardt (1991) advocates that L2 reading instruction should draw heavily on the use and analysis of recall data such as summary writing, paraphrasing, and synthesising.

Considering Bernhardt's principles discussed above, it is evident that a needs analysis is necessary in L2 reading instruction. This is echoed by Butler (2007) in his identification of key elements of a framework for academic writing course design in tertiary education. Although his elements relate to writing, the two skills are well integrated in the classroom and almost always taught together. Butler's elements comprise: (1) academic literacy and writing needs analysis; (2) description of textual features and requirements; (3) reader expectations and requirements; (4) institutional demands and constraints; (5) approach to teaching and learning; and (6) learning materials. Besides advocating a needs analysis, which is crucial in any L2 instruction, Butler's recommendation of soliciting 'reader expectations and requirements' in the academic context is justified by the concerns that have been raised on the dissonance between students' reading ability and or frames for reading on one hand, and lecturers' expectations on the other (Niven, 2005; Butler 2007; Brunfaut, 2008).

In addition to institutional demands, other constraints such as cultural and social issues impinge on L2 reading (Alderson, 2000; Grabe \& Stoller, 2002). Appropriate approaches to teaching, selection of learning materials and activities, as well as their relevance and authenticity, pertain to actual classroom management and relate to Guthrie and Wigfield's Knowledge goals and use of authentic and interesting texts respectively. The former, (knowledge goals) endorse an instructional approach that focuses on learning goals. The latter (authentic and interesting texts) favour the use of teaching materials or texts that are real, authentic, interesting and significant to students.

Butler's key elements, discussed above, resonate with humanistic approaches in the classroom, but, most importantly, relate to the socio-affective approach to reading instruction. Similarly, Kumaravadivelu's (2003) ten macrostrategies, which are underpinned by microstrategies in the form of classroom activities, are oriented towards a socio-affective approach.

\subsection{MACROSTRATEGIES FOR READING PEDAGOGY IN L2 TEACHING}

Kumaravadivelu (2003) lists ten macrostrategies for L2 teaching and learning, viz: (1) maximise learning opportunities; (2) minimise perceptual mismatches; (3) facilitate negotiated interaction; (4) promote learner autonomy; (5) foster language awareness; (6) activate intuitive heuristics; (7) contextualise linguistic input; (8) integrate language skills; (9) ensure social relevance and (10) raise cultural consciousness. These macrostrategies are discussed below and related to reading pedagogy.

\section{Maximise learning opportunities}

This macrostrategy refers to the creation of learning opportunities for learners. The assumption is that, by creating conditions necessary for learning, learners will be able to learn. Kumaravadivelu (2003) argues that the success of learning depends on the learner's willing cooperation to make use of the conditions created. His line of thought is that teaching, however purposeful, cannot automatically lead to learning for the simple reason that learning is primarily a personal construct controlled by the individual learner. He can choose either to 
learn or not. This underlies the contention that reading development/instruction that is solely cognitively oriented may not achieve optimal results. Dealing with the learner's affect, whereby he is personally motivated to learn, may be a significant way of maximising learning opportunities to produce higher outcomes. One of the classroom procedures or microstrategies suggested for this principle is to ask students to collect different perspectives on a topic, think critically about them (by analysing biases and opinions) and synthesise the different perspectives into one coherent report.

\section{Minimise perceptual mismatches}

This principle stresses the recognition of potential perceptual mismatches between the intentions and interpretations of the learner and teacher. A possible mismatch could be between input, what is available, and intake, what goes in. Intake or what constitutes learning is determined by how learners perceive the usefulness of classroom events such as activities and materials. Microstrategies that may be applied for this macrostrategy are: being explicit about what is being studied and why it is being studied and formulating clear outcomes for the various lesson units.

\section{Facilitating negotiated interaction}

Meaningful learner-learner and learner-teacher classroom interaction is to be encouraged and possibly facilitated by the teacher in order to allow learners to actively participate in classroom activities such as joint exploration of texts and the negotiated construction of texts. Students could be asked to research a chosen topic, write a one-page summary and create questions for discussion in class. Echoing Guthrie and Wigfield's (2000) words, Kumaravadivelu (2003) advises teachers to appreciate presenters' efforts. He explains that praise and appreciation for a student's effort is motivating and should not be overlooked.

\section{Promoting learner autonomy}

This macrostrategy involves equipping learners with the means necessary to self-direct and self-monitor their own learning. In other words, students take responsibility for their own learning. This principle of L2 learning is grounded in psychology: cognitive psychology states that the learner integrates knowledge with a personal framework; human psychology advocates that self-esteem is promoted through personal awareness of learning; educational psychology posits a strong connection between learner autonomy and learner motivation.

Learner autonomy is linked to strategy training. It is only when the learner is equipped that he can be able to take responsibility and self-monitor his own learning. Kumaravadivelu (2003) explains that learner autonomy includes equipping learners with the tools necessary to learn on their own and training them to use appropriate strategies for realising their learning objectives. Guthrie and Wigfield (2000) argue that students need explicit instruction and training in the use of strategies. This training enables them to develop self-efficacy, which is a contributing factor in reading development.

According to Kumaravadivelu (2003), strategies that need to be developed to promote learner autonomy are cognitive strategies for understanding, metacognitive strategies for coordinating the learning process, affective strategies for regulating emotions and attitudes and social strategies for learning and working with others. In creating autonomous learners, teachers 
should help learners to become aware of the wide range of alternative strategies available to them, and to create a learning environment where learners feel free to experiment.

As a step in providing students with autonomy through awareness and strategy training, he puts forward a microstrategy that is designed to help students know whether and how well they use inferencing as a strategy for improving their reading comprehension.

\section{Fostering language awareness}

This macrostrategy involves making students aware of how the language functions. In relation to reading development, the macrostrategy advocates the use of authentic materials and meaningful activities that resonate well with learners and their daily lives. For classroom activities, Kumaravadivelu (2003) recommends the use of textbooks to sensitise learners to subtle meanings, concealed assumptions and hidden attitudes embedded in a text. He suggests that a critical reading of texts could be followed by open-ended questions, respecting a variety views; different interpretations according to cultural perspectives; and critically reflecting on taken-for-granted views, which in his view could lend a motivating dimension to a text that would usually be a boring collection of linguistic input. Government reports, newspaper articles and journal articles are perceived as valuable additional sources.

\section{Activating intuitive heuristics}

This refers to the provision of rich textual data so that learners can make self-discoveries by inferring and internalising underlying rules governing grammatical usage and communicative use. Some classroom activities identified by researchers such as Anderson (1999), Alderson (2000) and Grabe and Stoller (2002) are: fill in blanks or cloze tests, reordering, classifying items into categories, and matching two sets of data according to some stated principle.

\section{Contextualising linguistic input}

This macrostrategy advocates that the four linguistic contexts, viz. linguistic contexts (cohesion features), extralinguistic contexts (prosodic features), situational contexts (nonlinguistic factors that frame interpretation and understanding) and extrasituational contexts (the social, cultural, political or ideological contexts that shape meaning in a particular speech event) are to be considered. In effect, context is of paramount importance in language communication. Effective communication should therefore integrate all four contextual factors. To this end Kumaravadivelu (2003) argues for linguistic input to be presented in units of texts so that learners can benefit from the interactive effect of various components and contexts. For classroom activities he suggests that selected texts should lend themselves to all four contexts, if possible.

\section{Integrating language skills}

This principle points to the integration of language skills (speaking, listening, reading and writing). Kumaravedivelu (2003) argues that, although many types of classroom activities, such as problem-solving, content-based activities, task-based activities, and project-based activities have entered the field of L2 learning and teaching, they all stress interactive language use that requires a synthesis of various language skills and various language components. 


\section{Ensuring social relevance}

The principle refers to the need for sensitivity to the societal, political, economic and educational environment in which L2 learning and teaching take place. In order to make L2 learning and teaching socially relevant, one has to recognise that the broader social, political, historical and economic conditions that affect the lives of learners and teachers also affect classroom aims and activities. For instance, the experiences that participants - teachers and learners - bring to the classroom are shaped not only by the learning and teaching episodes they have encountered in the past, but also by the broader social, economic and political environment in which they grew up. These experiences have the potential to affect classroom practices. In other words, learners' previous educational backgrounds, the community and the larger society exert great influence on classroom participants and management, and teachers cannot afford to ignore these socio-political and socio-cultural realities that influence identity formation in the classroom. Consequently, they cannot afford to separate the linguistic and literacy needs of learners from their social needs. Thus, reading proficiency is greatly influenced by students' social, economic and educational background and teachers cannot ignore these factors in developing their (academic) reading proficiency.

\section{Raising cultural consciousness}

This principle relates to the need to treat learners as cultural informants, in order to encourage them to engage in the process of classroom participation that recognises and elevates their power and knowledge. When learners are treated as cultural informants, they are encouraged to engage in a process of participation that projects and highlights their own power and knowledge. Using the learners' home culture to inform classroom activities enables students to become motivated and empowered. Niven (2005), discussing the conflict of frames between lecturers and students, states that "there needs to be a rapprochement of frames" between lecturers and students, and that lecturers should consider the diverse literacies and develop a more authentically indigenous South African academic culture (Niven, 2005:787).

\section{RELEVANT FACTORS IN L2 READING DEVELOPMENT}

From the discussion of second language reading and issues pertaining to academic reading at tertiary level (Bernhardt, 1991; Kumaravadivelu, 2003; Butler, 2007), the following factors, shown in blocks in the diagram, are proposed as crucial to the design of a reading programme. 


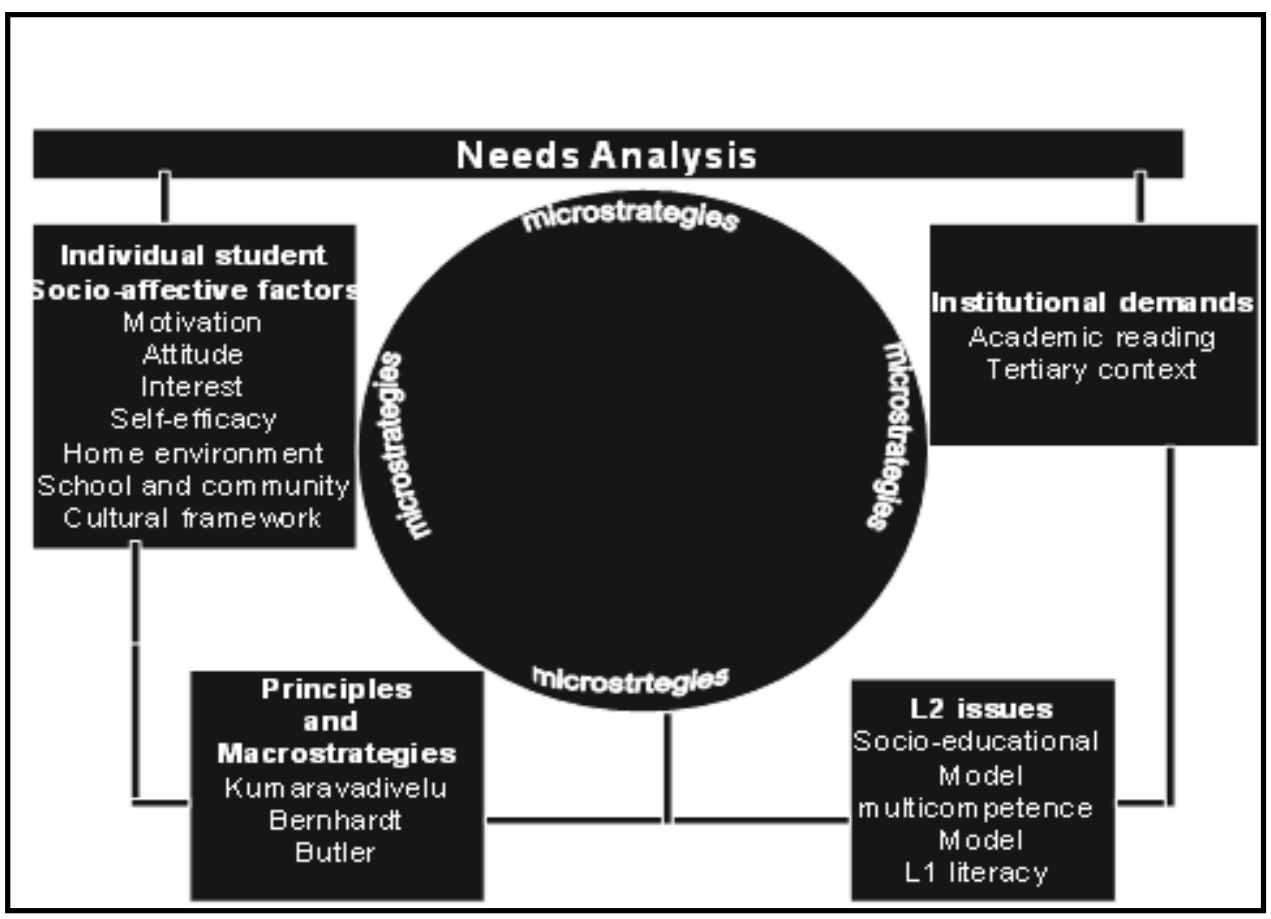

Figure 2: Relevant factors to be considered in developing L2 reading programmes

\section{A MULTIFACETED MODEL}

To emphasise issues pertaining to second language reading, such as those propounded by Bernhardt (1991), Kumaravadivelu (2003), and Butler (2007), Grabe and Stoller (2002) draw significant distinctions between L1 and L2 issues in reading development. They point out that L2 reading has its unique complexities, which should be highlighted in L2 reading development. Guthrie and Wigfield (2000), on the other hand, do not explicitly highlight L2 issues in reading, but their focus on the affective renders their model applicable for use in a context where a number of students lack the social and affective grounding in reading development. The model is therefore adopted, and important elements such as L2 reading issues, needs analysis, and academic and tertiary demands (for example, institutional constraints), are included for comprehensibility and specificity. The complete adapted model is presented below. 


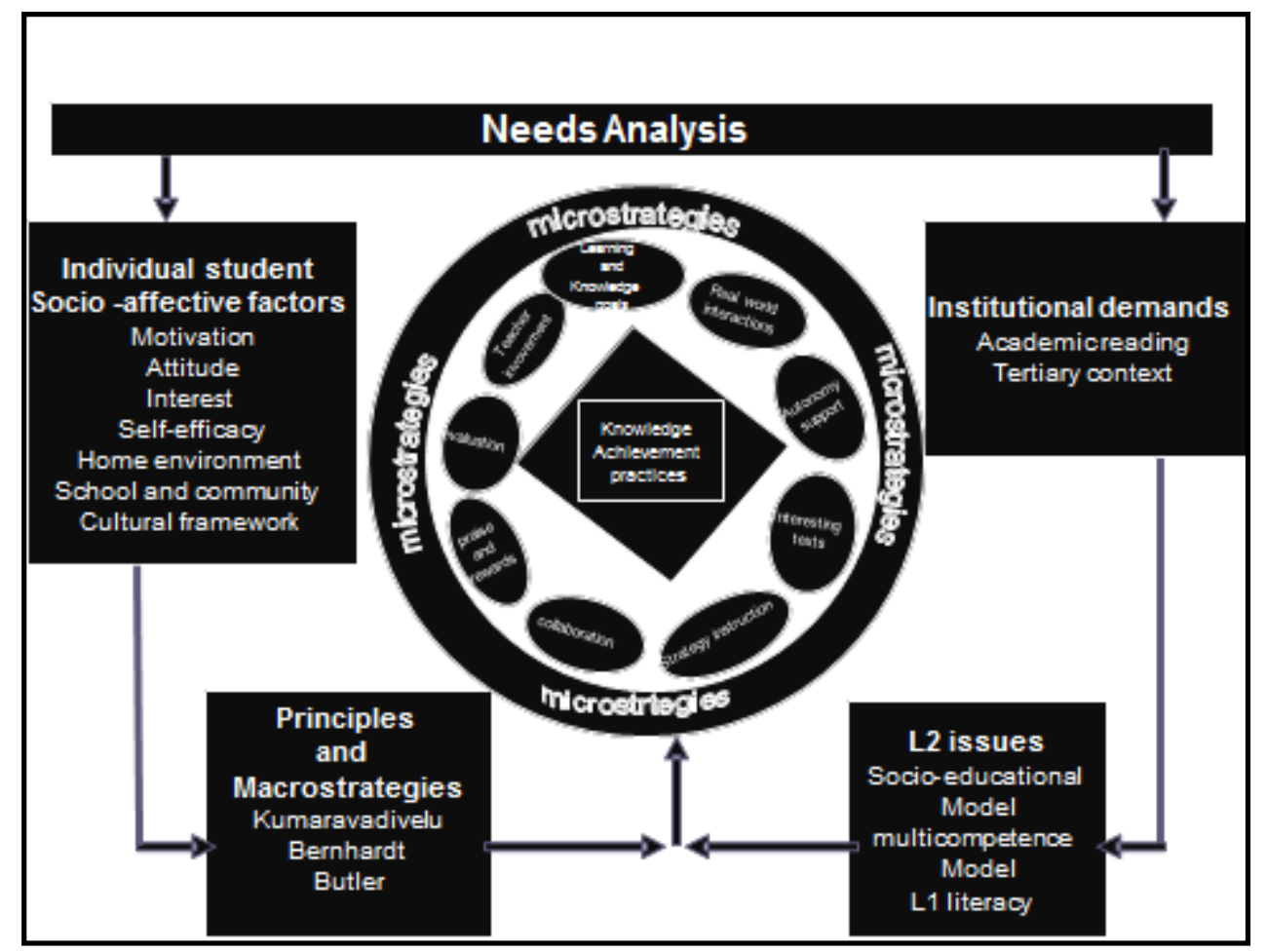

Fig 3: Multifaceted model for developing $L 2$ academic reading ability

The model comprises an attempt to integrate principles, elements and techniques to suit the South African context. Although the core of the design is based on Guthrie and Wigfield's (2000) Engagement model (as seen in the centre), it is situated in the context of academic reading at tertiary level, according to its institutional demands and disciplinary norms, as well as proficiency levels.

The constraint of the institutional context is the over-arching element in any teaching and learning situation. As much as the instructor is free to modify and adapt lessons, this freedom is curtailed by institutional constraints. Having considered these constraints, the first step the teacher needs to take is to conduct a needs analysis that will guide the teaching and learning. The needs analysis is conducted on two levels: needs derived from the students and needs derived from the institutional context (that is, the academic context and tertiary level demands). The institutional needs analysis can be conducted empirically from the lecturers as in Butler (2007) or from the experiential knowledge of the researcher and other colleagues. The needs analysis of the students is conducted via questionnaires and tests to ascertain the students' proficiency level, but most importantly to determine their social, affective and cognitive levels in relation to reading. As learning depends on the individual (Guthrie \& Wigfield, 2000; Kumavaradivelu, 2003), the importance of a needs analysis on students' social and affective levels to inform teaching cannot be overemphasised. Wallace (2003:21, 22) emphasises that, for L2 learners, social institutions such as the society and cultural identity, as well as the learner's background, play a significant role in the interpretation of texts.

The two-pronged needs analysis is brought to bear on the principles for L2 reading, macrostrategies and L2 issues (Bernhardt, 1991; Grabe \& Stoller, 2002; Kumaravadivelu, 2003), as discussed above. The results of the needs analysis, as well as the principles and 
microstrategies, together with L2 issues are all used to inform classroom activities and microstrategies. These microstrategies are then executed through Guthrie and Wigfield's (2000) instructional principles to provide engagement in reading. Engagement then produces desired outcomes of achievement, knowledge and practices in reading. Although the needs analysis from students and the institutional context influences teaching and learning in combination with, and through the principles and macrostrategies, they can also directly influence classroom management, such as teaching procedures, microstrategies, classroom activities and teaching materials. More specifically, the findings of the needs analysis should be used to draw up the classroom activities and tasks, select appropriate and significant texts, and emphasise areas of need within the principles and macrostrategies of L2 learning and reading.

\section{CONCLUSION}

The model is integrative in the sense that it does not consider reading development from a one-dimensional cognitive front, but from a multiplicity of factors. The social, affective, cognitive, L2 reading issues and the tertiary academic context are all considered in this multifaceted model which aims to develop and improve students' academic reading abilities. As Guthrie and Wigfield (2000:417) state:

Desired outcomes of teaching, such as text comprehension ability, knowledge acquisition from text, and sustainable reading practices, do not result automatically in response to instruction. These outcomes rely on engagement as a mediating process. Engagement is the avenue through which instruction impacts outcomes. Students grow in achievement, knowledge and practices as a result of their increasing engagement. And students' growing engagement flows from their continual experience of the instructional processes [discussed above].

This paper has discussed the relevance and importance of socio-affective factors in reading development. It has also pointed out the limited research in this area, and discussed the emphasis on cognitive aspects of reading in most reading programmes. A number of principles in L2 reading instruction and strategies in L2 learning have been discussed. Guthrie and Wigfield's (2000) model and framework for reading instruction, which focuses on socio-affective aspects of engagement, are presented and discussed, culminating in an adapted multifaceted model that takes into consideration needs analysis, the academic and tertiary context, and the multiplicity of factors relating to L2 reading instruction.

It is hoped that the multifaceted model and the framework discussed above will serve as guidelines for designing reading programmes and undertaking reading instructions that are multi-pronged, encompassing socio-affective and cognitive factors, as well as other relevant issues pertaining to $\mathrm{L} 2$ reading instruction.

\section{REFERENCES}

ALDERSON, JC. 2000. Assessing Reading. Cambridge: Cambridge University Press.

AMES, C. 1992. Classrooms: Goal, structures and student motivation. Journal of Educational Psychology, 84(3):261-271. 
ANDERSON, NJ. 1991. Individual differences in strategy use in second language reading and testing. The Modern Language Journal, 75(4):460-472.

ANDERSON, NJ. 1999. Exploring second language reading: Issues and strategies. Toronto: Heinle \& Heinle.

AU, KH \& CL ASAM. 1996. Improving the literacy achievement of low-income students of diverse backgrounds. In Graves, MF, P van den Broek \& BM Taylor (Eds), The first R: Every child's right to read. New York: Teachers College Press. 199-223.

BERNHARDT, E. 1991. Reading development in a second language: Theoretical, empirical and classroom perspectives. Norwood, NJ: Ablex Publishing.

BOAKYE, N. (forthcoming). Conducting a needs analysis: An investigation into the relationship between students' socio-affective profiles and their reading proficiency levels. Journal for Language Teaching.

BOUGHEY, C. 2009. South Africa: University students can't read [Online]. Available:www.universityworldnews.com/article.php?story=20090827173247724 chrissie [2009, August 31].

BRUNFAUT, T. 2008. Foreign language reading for academic purposes. Unpublished $\mathrm{PhD}$ thesis. University of Antwerp.

BROPHY, J. 1998. Motivating students to learn. Boston: McGraw-Hill.

BUS, A. 2001. Parent-child book reading through the lens of attachment theory. In Verhoeven, L \& C Snow (Eds), Literacy and motivation: Reading engagement in individuals and groups. Mahwah, NJ: Lawrence Erlbaum.

BUTLER, HG. 2007. A framework for course design in academic writing for tertiary education. Unpublished $\mathrm{PhD}$ thesis, University of Pretoria.

CSIKSZENTMIHALYI, M. 1991. Literacy and intrinsic motivation. In Graubard, SR (Ed), Literacy. New York: Harper and Row. 115-140.

DAY, R \& J BAMFORD. 1998. Extensive reading in the second language classroom. Cambridge: Cambridge University Press.

DECI, EL, RJ VELLERAND, LG PELLETIER \& MR RYAN. 1991. Motivation and education: The self-determination perspective. Educational Psychologist, 26:325-346.

DREYER, C \& C NEL. 2003. Teaching reading strategies and reading comprehension with a technology-enhanced learning environment. System, 31(3):349-365.

ELLEY, WB. 1996. Lifting literacy levels in developing countries. In Greany, V (Ed), Promoting reading in developing countries. Newark, Delaware:

International Reading Association. 39-54. 
GRABE, W \& F STOLLER. 2002. Teaching and researching reading. London: Pearson Education.

GREANEY, V. 1996. Reading in developing countries: Problems and issues. In Greaney, V (Ed), Promoting reading in developing countries. Washington DC: International Reading Association.

GROLNICK, WS \& RM RYAN. 1987. Autonomy in children's learning: An experimental and individual difference investigation. Journal of Personality and Social Psychology, 52: 890-898.

GUTHRIE, JT, P VAN METER, GR HANCOCK, S ALAO, E ANDERSON \& A MCCANN. 1998. Does concept-oriented reading instruction increase strategy use and conceptual learning from text? Journal of Educational Psychology, 90: 261-278.

GUTHRIE, JT, A WIGFIELD, JL METSALA \& KE COX. 1999. Motivational and cognitive predictors of text comprehension and reading amount. Scientific Studies of Reading, 3(3):231-256.

GUTHRIE, JT, E ANDERSON, S ALAO \& J RINEHART. 1999. Influences on conceptoriented reading instruction on strategy use and conceptual learning from text. Elementary School Journal, 99:343-366.

GUTHRIE, JT, A WIGFIELD \& C VON SECKER. 2000. Effects of integrated instruction on motivation and strategy use in reading. Journal of Educational Psychology, 92:331-341.

GUTHRIE, JT \& A WIGFIELD. 2000. Engagement and motivation in reading. In Kamil, ML, PB Mosenthal, PD Pearson \& R Barr. Handbook of reading research. Vol III. 403422.

KUMARAVADIVELU, B. 2003. Beyond methods: Macrostrategies for language teaching. New Haven: Yale University Press.

MORROW, LM. 1996. Motivating reading and writing in diverse classrooms. Urbana, IL: National Council of Teachers of English.

NIVEN, P. 2005. Exploring first year students' and their lecturers' constructions of what it means to read in a humanities discipline: A conflict of frames? South African Journal of Higher Education, 19(4):777-789.

NOLEN, SB \& JG NICHOLS. 1994. A place to begin (again) in research on student motivation: Teachers' beliefs. Teaching and Teacher Education, 10:57-69.

PRETORIUS, E. 2000. Inference generation in the reading of expository texts by university students. Unpublished doctoral dissertation, University of South Africa.

PRETORIUS, E. 2002. Reading ability and academic performance in South Africa: Are we fiddling while Rome is burning? Language Matters, 33:91-103. 
PRETORIUS, E. 2007. Looking into the seeds of time: Developing academic literacy in high poverty schools. Ensovoort,11(2):105-125.

SCHUNK, DH \& BJ ZIMMERMAN. 1997. Developing self-efficacious readers and writers: The role of social and self-regulatory processes. In Guthrie, JT \& A Wigfield (Eds), Reading engagement: Motivating readers through integrated instruction. Newark, DE: International Reading Association. 34-50.

SERPELL, R. 2001. Literacy empowerment in developing societies. In Verhoeven, L \& CE Snow (Eds), Literacy and motivation. London: Lawrence Erlbaum. 222-250.

SKINNER, EA, JG WELLBORN JP CONNELL. 1990. What it takes to do well in school and whether I've got it: A process model of perceived control and children's engagement and achievement in school. Journal of Educational Psychology, 82:22-32.

STANOVICH, KE \& AE CUNNINGHAM. 1993. Where does knowledge come from? Specific associations between print exposure and information acquisition. Journal of Education Psychology, 85(2):211-229.

STANOVICH, K. 1986. Matthew effects in reading: Some consequences of individual differences in the acquisition of literacy. Reading Research Quarterly, 16:32-71.

STREET, B. 2001.Cultural dimensions of literacy promotion and schooling. In Verhoeven, L \& CE Snow (Eds), Literacy and motivation. London: Lawrence Erlbaum. 265-273.

SWEET, A, JT GUTHRIE \& MM NG. 1998. Teacher perceptions and student reading motivation. Journal of Educational Psychology, 90:210-223.

VERHOEVEN, L \& CE SNOW. 2001. Literacy and motivation. London: Lawrence Erlbaum.

WALLACE, C. 2003. Critical reading in language education. Basingtone: Palgrave Macmillan.

WENTZEL, KR. 1997. Student motivation in middle school: The role of perceived pedagogical caring. Journal of Educational Psychology, 89:411-419.

WLODKOWSKI, R. 1985. Enhancing adult motivation to learn. San Francisco: Jossey Bass.

WORDEN, R. 2003. The teaching of explicit reading comprehension strategies Improves reading and more [Online]. Available: http://ltn.themic.org/Evidence-based_Practice.html 2010, April 21].

\section{BIOGRAPHICAL NOTE}

Naomi Boakye is a lecturer in the Unit for Academic Literacy at the University of Pretoria. Her research interests are in Applied Linguistics (L2 reading) and Sociolinguistics. 